\title{
Incidence of butt rot in Norway spruce seed stands in Poland's mountain regions assessed with sonic tomography
}

\section{Elżbieta Chomicz}

Forest Research Institute, Department of Mountain Forestry, Fredry 39, 30-605 Kraków, Poland, phone: +48122528214 , e-mail: E.Chomicz@ibles.waw.pl

\begin{abstract}
The incidence and severity of butt rot were assessed in 12 selected Norway spruce seed stands in the Beskidy Mountains, Poland. A semi-invasive technique of sonic tomography was used for the assessment of rot damage. Stands of different age classes (100-120, 130-150, 160-170 years old) and distinct regions of provenance (Istebna and Orawa) were investigated. Hierarchical analysis of variance was used to determine effects of stand age and stand provenance on butt rot occurrence at a stand level. High incidence of butt rot was noted in all of the studied seed stands $(47 \%$ to $87 \%$ of diagnosed tree samples). Stand age had a significant effect on percentage share of 'damaged wood' on the tomogram. The extent of rot damage was rising with stand age, and the largest was observed in the age category 160-170 years. Spruce stands of Istebna provenance were generally more damaged by butt rot than those of Orawa provenance, however, the latter have been growing in forest sites more suitable for spruce in terms of fertility and altitude. Hierarchical analysis of variance did not show a statistically significant relationship between the region of provenance and average share of 'damaged wood' on the tomogram. Presented results indicate that for stands growing in similar conditions vulnerability to butt rot is determined by stand age. Further research is needed to separate impact of stand provenance identified with specific genetic constitution of a population from the effect of environmental conditions typical of a given region of provenance.
\end{abstract}

\section{KeY WORDS}

Picea abies, Picus sonic tomography, rot damage, overmature stands, region of provenance, stand age

\section{INTRODUCTION}

Norway spruce [Picea abies (L.) Karst.] belongs to dominant tree components of forest stands in mountain regions of Poland. One of the major problems in this species management is its susceptibility to root and butt rot caused by fungi. Presence of decay at the bottom of a tree trunk means not only depreciation of the most valuable timber and severe economic losses for forest industry (Asiegbu et al. 2005; Kaliszewski et al. 2007), but also an increased risk of wind damage (Lakomy et al. 2001), which poses a serious threat to sustainability of mountain forests. As butt rot in spruce affects physiologically inactive heartwood, decay can proceed for 
many years without any external signs of wood damage. Due to lack of distinct relationship between the presence of butt rot and general condition of a tree (Vollbrecht, Agestam 1995), decay in Norway spruce can be often discerned only after cutting a tree down.

Previous investigations on butt rot incidence were based mainly on visual stump assessments (Lindén, Vollbrecht 2002; Rönnberg et al. 2007), and in case of standing trees - on analyses of increment cores taken at breast height (Mattila, Nuutinen 2007) or from the area of root collar (Krzan 1985). These approaches provide approximate information on the presence and severity of butt rot at a stand level. According to Habermehl and Ridder (1979), however, precise assessment of butt rot occurrence in older spruce stands can be made exclusively with two methods: stem analysis after cutting of all spruce trees on a research plot or with the aid of computer tomography.

As the consequence of past management practices, forests of the Beskid Śląski and Żywiecki (southern Poland) have unnaturally huge participation of Norway spruce in species composition. At the same time, in these areas, there reside the most valuable provenances of Norway spruce in a whole range of the species, currently excluded from forest utilization as selected seed stands and destined for producing forest regeneration material. These are predominantly very old stands, reaching the age of 160 years and more, considerably exceeding rotation age approved for Norway spruce. It is assumed that elitism of selected seed stands refers also to their good health, i.e. lack of pathogenic organisms (Matras, Fonder 2006). However, it is known that trees in advanced age are highly susceptible to butt rot occurrence (Bernadzki 2003; Barszcz 2004). With regard to latent character of decay process in spruce stems as well as exclusion from forest utilization, there is lack of information on the extent of butt rot damages in these seed stands.

The aim of the study was to determine the incidence and severity of butt rot in selected Norway spruce seed stands in the Beskidy Mountains, Poland, with the aid of a novel diagnostic method - sonic tomography. Spruce stands of different age classes were investigated in order to determine a relationship between rising stand age and frequency of butt rot occurrence in overmature stands. The stands studied represent distinct regions of provenance, namely Istebna provenance and Orawa provenance, which allowed to ascertain potential differences in resistance to butt rot between the two Carpathian spruce races.

\section{Material AND Methods}

\section{Study Sites}

The study covered 12 Norway spruce seed stands located in the Beskid Śląski and Żywiecki (western edge of the Carpathians) in Poland, registered in the national register of forest basic material in the 'selected' category. The stands represented 3 age groups and 2 regions of provenance (tab. 1).

\section{Sonic tomography}

In each stand, 30 trees were randomly chosen and decay in their trunks was assessed with the aid of the Picus Sonic Tomograph (Argus Electronics GmbH, Rostock, Germany). Sonic tomography is a semi-invasive technique (only bark layer is penetrated with sensor pins just to get in contact with sapwood) that utilizes sound waves to quantify and locate decay on

Tab. 1. Localization and characteristic of studied seed stands

\begin{tabular}{|c|c|c|c|c|c|c|}
\hline $\begin{array}{l}\text { Prov- } \\
\text { enance }\end{array}$ & $\begin{array}{l}\text { Age } \\
\text { group } \\
\text { (yrs) }\end{array}$ & $\begin{array}{l}\text { Stand name/ } \\
\text { code }\end{array}$ & $\begin{array}{l}\text { Forest } \\
\text { district }\end{array}$ & $\begin{array}{l}\text { Lati- } \\
\text { tude }\end{array}$ & $\begin{array}{l}\text { Longi- } \\
\text { tude }\end{array}$ & $\begin{array}{l}\text { Altitude } \\
\text { (m a.s.1.) }\end{array}$ \\
\hline \multirow{6}{*}{ Istebna } & \multirow{2}{*}{$160-170$} & Bukowiec 1/B1 & Wisła & $49^{\circ} 34^{\prime}$ & $18^{\circ} 50^{\prime}$ & $530-740$ \\
\hline & & Bukowiec 2/B2 & Wisła & $49^{\circ} 34^{\prime}$ & $18^{\circ} 50^{\prime}$ & $460-690$ \\
\hline & \multirow{2}{*}{$130-150$} & Zapowiedź 1/Z1 & Wisła & $49^{\circ} 34^{\prime}$ & $18^{\circ} 50^{\prime}$ & $540-640$ \\
\hline & & Gawłowskie/G & Ujsoły & $49^{\circ} 31^{\prime}$ & $19^{\circ} 14^{\prime}$ & $790-1160$ \\
\hline & \multirow{2}{*}{$100-120$} & Zapowiedź 2/Z2 & Wisła & $49^{\circ} 32^{\prime}$ & $18^{\circ} 55^{\prime}$ & $580-690$ \\
\hline & & Dzięgielów/D & Ustroń & $49^{\circ} 41^{\prime}$ & $18^{\circ} 46^{\prime}$ & $530-720$ \\
\hline \multirow{6}{*}{ Orawa } & \multirow{2}{*}{$160-170$} & Stańcowa 1/S1 & Nowy Targ & $49^{\circ} 33^{\prime}$ & $19^{\circ} 33^{\prime}$ & $975-1075$ \\
\hline & & Stańcowa 2/S2 & Nowy Targ & $49^{\circ} 33^{\prime}$ & $19^{\circ} 33^{\prime}$ & $875-1000$ \\
\hline & \multirow{2}{*}{$130-150$} & Stańcowa 3/S3 & Nowy Targ & $49^{\circ} 33^{\prime}$ & $19^{\circ} 32^{\prime}$ & $925-1050$ \\
\hline & & Police 1/P1 & Nowy Targ & $49^{\circ} 35^{\prime}$ & $19^{\circ} 36^{\prime}$ & $880-1070$ \\
\hline & \multirow{2}{*}{$100-120$} & Stańcowa 4/S4 & Nowy Targ & $49^{\circ} 33^{\prime}$ & $19^{\circ} 34^{\prime}$ & $925-1250$ \\
\hline & & Police 2/P2 & Nowy Targ & $49^{\circ} 35^{\prime}$ & $19^{\circ} 36^{\prime}$ & $885-1110$ \\
\hline
\end{tabular}


cross section of a tree trunk (Rust, Göcke 2000; Rabe et al. 2004). The Picus Sonic Tomograph consists of a set of sensors that are connected to a trunk by pins. Sound waves are produced by tapping each pin with a hammer. The Picus system measures the transmission time from each impact with hammer to each sensor. By measuring the distances between sensors apparent sound velocities are calculated by a software system, based on which wood density is determined. Using the data obtained, a two-dimensional image (tomogram) of cross section is generated. Users of Picus tomographs point out to high reliability of sonic measurements in internal tree decay assessments (Gilbert, Smiley 2004; Rabe et al. 2004).

Tomograph measurements were taken at the bottom of tree trunk, $10-30 \mathrm{~cm}$ above the ground level. Eight to 10 measurement points were used, depending on tree size. Sensor pins were spaced around the trunk and driven into sapwood in a horizontal plane according to manufacturer instructions. The sensor was magnetically attached to each pin and tapped three times with an electronic hammer version Lite. The exact shape of the cross-section investigated was determined by measurement of adequate distances between sensors with the Picus Calliper. Tomograms were calculated using Picus PC Programm Version Q71.6.

Wood of each tree trunk cross-section was qualified to one of 3 categories: 'solid wood' (dark and light brown color on the tomogram), 'damaged wood' (blue and violet color) or 'unidentified wood' (green color). A share of each wood category was calculated automatically by Picus software, as a percentage of proper color area to the whole tomogram area.
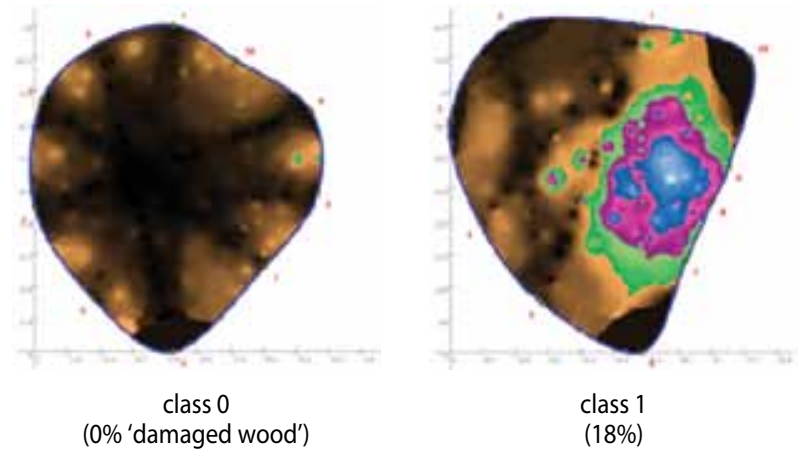

Fig. 1. Tomograms in damage classes - examples
Each investigated tree was assigned to one of 4 damage classes, according to percentage share of 'damaged wood' category within the tomogram: class 0 -0 to $5 \%$, class $1-6$ to $25 \%$, class $2-26$ to $50 \%$, class 3 - 51 to $100 \%$ of 'damaged wood' on the tomogram. Tomogram examples presented below (fig. 1) illustrate the extent of decay in each class.

\section{Statistical Analyses}

Seed stands studied were compared with regard to average share of 'damaged wood' category on the tomogram. With respect to data character, Bliss transformation was used for variance stabilization. Multi-factor ANOVA was used to compare stands of Istebna and Orawa provenances among age categories and to contrast every stand against each other. A hierarchical approach was used according to the model:

$$
Y_{i j k n}=\mu+R_{i}+A(R)_{i j}+L(A * R)_{i j k}+E_{i j k n}
$$

where

$Y_{i j k n} \quad-$ the observed value for the variable considered in the $n$ tree from the $i$ region of provenance of the $j$ age category into the $k$ localization

$\mu \quad-$ the overall mean,

$R_{i} \quad-$ the fixed effect of the $i$ region of provenance,

$A(R)_{i j} \quad$ - the random effect of the $i$ age category nested within the $j$ region of provenance,

$L\left(A^{*} R\right)_{i j k}$ - the random effect of the $k$ localization nested within the $j$ age category into the $i$ region of provenance,

$E_{i j k n} \quad-$ the residual error for $Y_{i j k n}$.
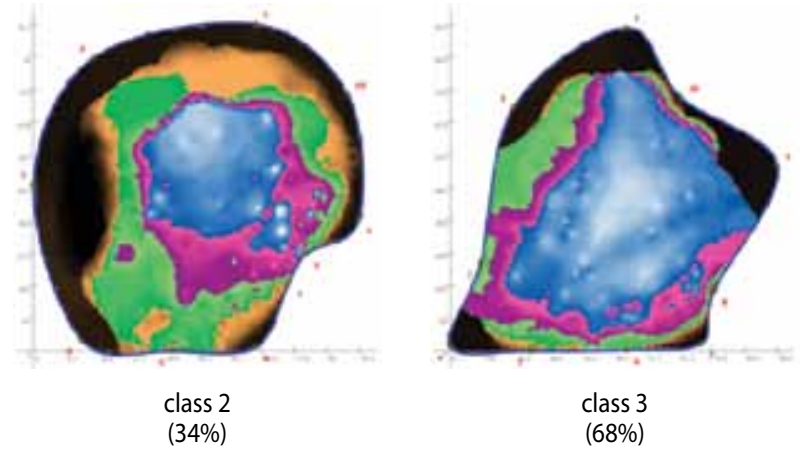
Homogenous groups were obtained by Tukey's HSD test. All calculations were conducted using Statistica 9.0" software package (Stat Soft Inc. USA).

\section{Results}

High incidence of butt rot was noticed in all studied seed stands, ranging from $47 \%$ of diagnosed tree samples in $\mathrm{S} 3$ stand to $87 \%$ in the $\mathrm{B} 1$ and $\mathrm{Z} 1$ (tab. 2). The mean for stand percentage of 'damaged wood' category on the tomogram roughly corresponded with the share of trees affected by butt rot in investigated tree samples (tab. 3).

Tab. 2. Number of trees in damage classes and respective percentages

\begin{tabular}{|c|c|c|c|c|c|c|c|c|c|c|c|c|c|}
\hline \multicolumn{14}{|c|}{ A. Istebna provenance } \\
\hline \multirow{2}{*}{ Stand } & & \multicolumn{2}{|c|}{ B1 } & \multicolumn{2}{|c|}{ B2 } & \multicolumn{2}{|c|}{$\mathrm{Z} 1$} & \multicolumn{2}{|c|}{$\mathrm{G}$} & \multicolumn{2}{|c|}{$\mathrm{Z} 2$} & \multicolumn{2}{|c|}{$\mathrm{D}$} \\
\hline & & $n$ & $\%$ & $n$ & $\%$ & $n$ & $\%$ & $n$ & $\%$ & $n$ & $\%$ & $n$ & $\%$ \\
\hline \multirow{4}{*}{ Class } & 0 & 4 & 13 & 12 & 40 & 4 & 13 & 10 & 33 & 15 & 50 & 12 & 40 \\
\hline & 1 & 12 & 40 & 14 & 47 & 20 & 67 & 13 & 43 & 9 & 30 & 8 & 27 \\
\hline & 2 & 11 & 37 & 4 & 13 & 6 & 20 & 7 & 23 & 3 & 10 & 10 & 33 \\
\hline & 3 & 3 & 10 & - & - & - & - & - & - & 3 & 10 & - & - \\
\hline \multicolumn{2}{|c|}{$\begin{array}{l}\text { Sum } \\
(1-3)\end{array}$} & 26 & 87 & 18 & 60 & 26 & 87 & 20 & 67 & 15 & 50 & 18 & 60 \\
\hline \multicolumn{14}{|c|}{ B. Orawa provenance } \\
\hline \multirow{2}{*}{\multicolumn{2}{|c|}{ Stand }} & \multicolumn{2}{|c|}{ S1 } & \multicolumn{2}{|c|}{ S2 } & \multicolumn{2}{|c|}{ S3 } & \multicolumn{2}{|c|}{$\mathrm{P} 1$} & \multicolumn{2}{|c|}{ S4 } & \multicolumn{2}{|c|}{$\mathrm{P} 2$} \\
\hline & & $n$ & $\%$ & $n$ & $\%$ & $n$ & $\%$ & $n$ & $\%$ & $n$ & $\%$ & $n$ & $\%$ \\
\hline \multirow{4}{*}{ Class } & 0 & 9 & 30 & 6 & 20 & 16 & 53 & 9 & 30 & 15 & 50 & 13 & 43 \\
\hline & 1 & 13 & 43 & 12 & 40 & 10 & 33 & 16 & 53 & 10 & 33 & 10 & 33 \\
\hline & 2 & 7 & 23 & 11 & 37 & 3 & 10 & 5 & 17 & 5 & 17 & 6 & 20 \\
\hline & 3 & 1 & 3 & 1 & 3 & 1 & 3 & - & - & - & - & 1 & 3 \\
\hline \multicolumn{2}{|c|}{$\begin{array}{l}\text { Sum } \\
(1-3)\end{array}$} & 21 & 70 & 24 & 80 & 14 & 47 & 21 & 70 & 15 & 50 & 17 & 57 \\
\hline
\end{tabular}

Upon hierarchical analysis of variance it was concluded that there were statistically significant differences in butt rot incidence among studied seed stands (significant effect of 'localization' factor nested in 'age group' factor; $F=2.747 ; p=0.013$ ). 'Age group' factor had a significant effect on percentage share of 'damaged wood' on the tomogram (significant effect of 'age group' factor nested in 'region of provenance' factor; $\mathrm{F}=4.258 ; \mathrm{p}=0.002$ ). The extent of rot damage was rising with stand age and the largest was in the age category 160-170 years (fig. 2). The exception was B2 stand, with distinctly fewer tree trunks with butt rot $(60 \%$ of studied tree samples; tab. 2) and lower share of 'damaged wood' on the tomogram (12\%; tab. 3$)$ than the rest of stands in the oldest age category. One-way ANOVA conducted for stands in the age category 160-170 years showed that average share of 'damaged wood' on the tomogram in B2 stand was significantly lower than that in $\mathrm{B} 1(\mathrm{p}=0.005)$ and the $\mathrm{S} 2(\mathrm{p}=0.050)$ stands.

Tab. 3. Average percentage of 'damaged wood' category on the tomogram

\begin{tabular}{|c|c|c|c|c|c|c|c|c|c|c|c|c|}
\hline Stand & B1 & B2 & Z1 & G & Z2 & D & S1 & S2 & S3 & P1 & S4 & P2 \\
\hline $\begin{array}{c}\text { Damaged } \\
\text { wood (\%) }\end{array}$ & 27 & 12 & 19 & 15 & 14 & 17 & 19 & 22 & 11 & 14 & 11 & 15 \\
\hline
\end{tabular}

Spruce stands of Istebna provenance were generally more damaged by butt rot than of Orawa provenance. The opposite situation was observed only in stands of the age category $160-170$ years (fig. 2), as a result of relatively low share of 'damaged wood' in the B2 stand,

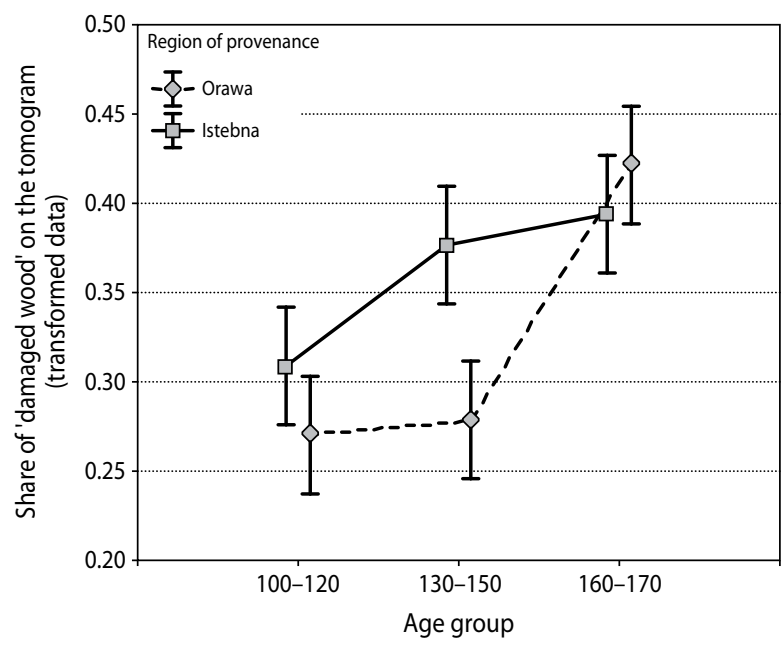

Fig. 2. Comparison of stands of two regions of provenance according to age groups (marker - arithmetic mean, whisker - standard deviation) 
which significantly decreased the mean value for the oldest stands of Istebna spruce. Hierarchical analysis of variance did not show a statistically significant relationship between the region of provenance and average share of 'damaged wood' on the tomogram (no significant effect of 'region of provenance' factor; $\mathrm{F}=1.831$; $\mathrm{p}=0.177$ ). However, when B2 stand was excluded from the analysis, both the age group (significant effect of 'age group' factor nested in 'region of provenance' factor; $F=6.077 ; p<0.000$ ) and the region of provenance (significant effect of 'region of provenance' factor; $\mathrm{F}=4.773 ; \mathrm{p}=0.030$ ) had a significant impact on the extent of butt rot damage in the studied stands. Average share of 'damaged wood' on the tomogram was clearly increased with the stand age and was higher in stands of Istebna spruce in every age group (fig. 3).

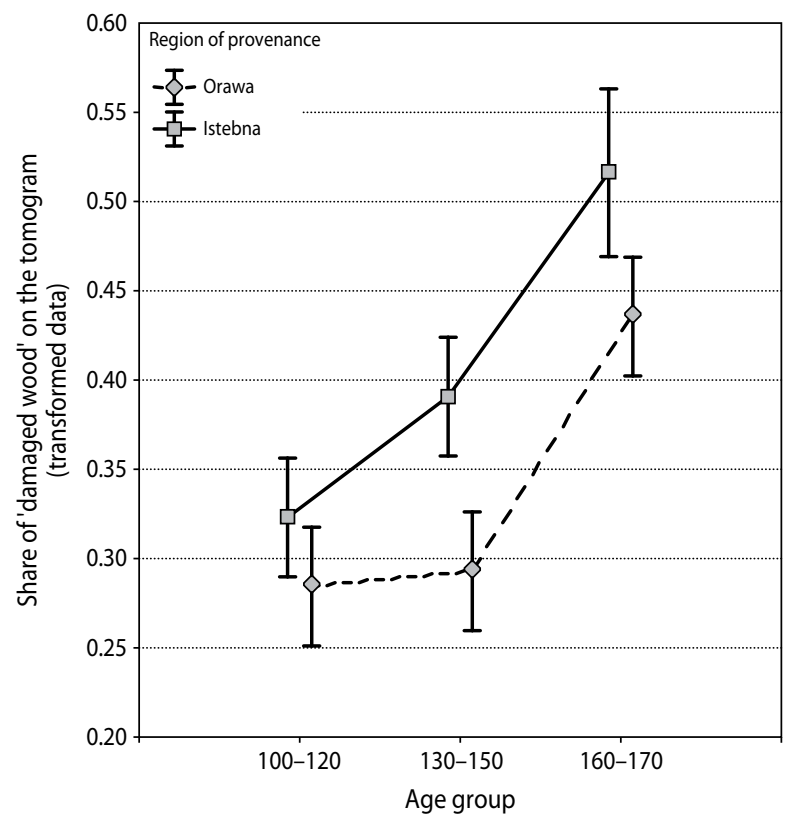

Fig. 3. Comparison of stands of two regions of provenance according to age groups, excluding B2 stand (marker - arithmetic mean, whisker - standard deviation)

\section{Discussion}

High incidence of butt rot was noted in all studied seed stands. In each case, decay was found in at least half of the diagnosed tree samples. Such a poor quality of spruce wood was a consequence of stand age. The research was conducted in overmature stands, and ad- vanced age is connected with intensification of natural processes of wood decomposition (Barszcz 2004). As Bernadzki (2003) states, when keeping trees untill very old age, high risk of decay should be taken into account, the risk which rises fast with stand age. Therefore, rotation age of managed spruce stands should be optimized, even shortened in some cases, taking into account potential economic losses from timber deterioration as well as reduction of forest stability. It is not the issue in the case of seed stands, the main function of which is not timber but seed production, still even there the timing of felling should be reasonably determined so as to ensure genetically the richest natural regeneration.

According to Norokorpi (1980), butt rot affects spruce stands already when they are under 100 years, and at the age of 300-400 years, probably all spruce trees are spoiled by decay. When assessing the incidence of butt rot in old spruce stands in Finland, Norokorpi (1980) stated that frequency of decay was increasing by about $0.2-0.3 \%$ per year. Presented tomographic research conducted in seed stands with various age groups confirmed, that the age of trees had a significant effect on butt rot incidence in the stand. A degree of butt rot damage, measured by percentage of 'damaged wood' category on the tomogram, was clearly increasing with rising stand age. The only exception was B2 stand, significantly less damaged by rot than B1 stand, ranked to the same age group and located in close proximity of the same forest sub-district. It is difficult to settle if there are some differences in genetic constitution of both population that influence their resistance to butt rot or else the lesser vulnerability is just a simple outcome of different environmental conditions. According to forest survey report, B1 stand has been growing on brown soil, while B2 stand - on less fertile rusty soil. There are explicit evidences that spruce trees which grow on fertile forest sites are more affected by root and boot rot than those on poorer sites (Lech, Żółciak 2006; Mareš 2010).

In the focus of conducted tomographic study, as far as statistics is concerned, there was no significant effect of the region of provenance on the degree of rot damage in the stand. However, these results could be an effect of small number of stands covered by the study resulted in analysis sensitivity to untypical observations. The results of the study indicate the significant relationship between region of provenance and butt rot incidence in 
the stand, if only B2 stand was excluded from statistical analysis. Istebna provenance stands were damaged by butt rot to a greater extent than those of Orawa provenance from the same age group. There remains a question whether observed differences are results of distinct genetic properties of populations present in two regions of provenance or just results from different environmental conditions of these regions. In comparison to Istebna provenance, stands of Orawa provenance - less damaged by rot - were growing in forest sites more suitable for spruce in terms of fertility (poor sites) and altitude (high altitude). It was observed that the extent of decay generally decreases while altitude of spruce stand rises, which is connected with higher precipitation, lower temperature and shorter vegetation period on higher elevations (Twarowski, Twarowska 195; Barszcz 2004). Tomographic investigations conducted in spruce stand of the Wantule strictly protected area in the Tatra National Park, Poland (Niemtur, Chomicz 2008), reached similar conclusions. Percentage of spruce trees with butt rot in the Wantule reserve ( $40 \%$ of investigated tree samples) was less than a half of that observed in B1 stand (87\%), despite the similar age of both stands (about 170 years). On the other hand, the Wantule reserve is located on a poor site at high altitude (1170-1350 m a.s.1.) while B1 stand has been growing on a fertile site at lower altitude (530-740 $\mathrm{m}$ a.s.1.).

\section{Conclusions}

Presented results indicate that vulnerability to butt rot is determined by stand age, in case of stands located in similar conditions. Incidence of decay clearly increases with age of trees. However, further research is needed to separate impact of stand provenance identified with specific genetic constitution of a population, from the influence of environmental conditions typical of a given region of provenance. The sonic tomography can be a useful tool to identify distinctly less damaged populations or quite sound individuals for further genetic and ecological research on the basis of diverse resistance to butt rot in Norway spruce. As a destructive effect of sonic measurement is reduced to the minimum, even the most valuable populations, such as selected seed stands or stands protected in nature reserves, can be included in these research.

\section{AcknOWLedgements}

Great thanks to Mariusz Kapsa for his invaluable help in all field work.

\section{References}

Asiegbu F.O., Adomas A., Stenlid J. 2005. Conifer root and butt rot caused by Heterobasidion annosum (Fr.) Bref. s.1. Molecular Plant Pathology, 6 (4), 395-409.

Barszcz A. 2004. The dependency of the quality and size structure and of the value of timber on the origin and age of stands. EJPAU, 7 (2), 8 [online journal]. http://www.ejpau.media.pl/volume7/issue2/forestry/ art-08. Accessed 19 June 2013.

Bernadzki E. 2003. Struktura wieku i zagrożenie zgnilizną drewna starych drzewostanów sosnowych. Sylwan, 5, 3-12.

Gilbert E.A., Smiley E. 2004. Picus sonic tomography for the quantification of decay in white oak (Quercus alba) and hickory (Carya spp.). Journal of Arboriculture, 30 (5), 277-280.

Habermehl A., Ridder H.W. 1979. Zerstörungsfreies Verfahren und Gerät zum Nachweis von Stammfäulen am Stehenden Stamm. Allgemeine Forst Zeitschrift, 34 (28), 754-759.

Kaliszewski A., Lech P., Oszako T. 2007. The occurrence of, and economic losses caused by Armillaria in the Western Carpathian Mts. Acta Mycologica, 42 (2), 219-233.

Krzan Z. 1985. Występowanie zgnilizny odziomkowej świerków w drzewostanach regla dolnego Tatrzańskiego Parku Narodowego. Parki Narodowe $i$ Rezerwaty Przyrody, 6 (2), 5-16.

Lech P., Żółciak A. 2006. Uwarunkowania występowania opieńkowej zgnilizny korzeni w lasach Beskidu Żywieckiego. Leśne Prace Badawcze, 2, 33-49.

Lindén M., Vollbrecht G. 2002. Sensitivity of Picea abies to butt rot in pure stands and in mixed stand with Pinus sylvestris in southern Sweden. Silva Fennica, 36 (4), 767-778.

Łakomy P., Cieślak R., Rodak W., Kostrzewski T. 2001. Wpływ porażenia przez Heterobasidion annosum wybranych drzewostanów sosnowych i świerkowych na powstanie wiatrołomów i wiatrowałów w 1999 i 2000 roku. Sylwan, 7, 43-54. 
Mareš R. 2010. The extent of root rot damage in Norway spruce stands established on fertile sites of former agricultural land. Journal of Forest Science, 56 (1), 1-6.

Matras J., Fonder W. 2006. Wytyczne w sprawie ochrony leśnych zasobów genowych na potrzeby nasiennictwa i hodowli drzew leśnych. Załącznik nr 1 do Zarządzenia nr 7A z 7 kwietnia 2006 r. dyrektora generalnego LP. Warszawa.

Mattila U., Nuutinen T. 2007. Assessing the incidence of butt rot in Norway spruce in southern Finland. Silva Fennica, 41 (1), 29-43.

Niemtur S., Chomicz E. 2008. Tomografia komputerowa świerków w zagrożonych drzewostanach o różnym statusie ochronnym. Problemy Zagospodarowania Ziem Górskich, 55, 99-112.

Norokorpi Y. 1980. Old Norway spruce stands, amount of decay and decay causing microbes in northern Finland. Communicationes Instituti Forestalis Fenniae, 97 (6), 1-77.
Rabe C., Ferner D., Fink S., Schwarze F.W.M.R. 2004. Detection of decay in trees with stress waves and interpretation of acoustic tomograms. Arboricultural Journal, 28, 3-19.

Rönnberg J., Berglund M., Johansson U. 2007. Incidence of butt rot at final felling and at first thinning of the subsequent rotation of Norway spruce stands in south-western Sweden. Silva Fennica, 41 (4), 639-647.

Rust S., Göcke L. 2000. A new tomographic device for the non-destructive testing of standing trees. In: Proceedings of the 12th International Symposium on Nondestructive Testing of Wood. 13-15 September 2000, Sopron, Hungary, 233-238.

Twarowski Z., Twarowska I. 1959. Studia i obserwacje nad opieńką miodową Armillaria mellea (Vahl.) Quel. jako przyczyną masowego zamierania drzewostanów. Prace IBL, 192, 1-62.

Vollbrecht G., Agestam E. 1995. Identifying butt rotted Norway spruce trees from external signs. Forest and Landscape Research, 1, 241-254. 